\title{
Differences in dietary pattern between obese and eutrophic children
}

\author{
Emilia A Balthazar ${ }^{1 \dagger}$ and Maria RM de Oliveira ${ }^{1,2^{* \dagger}}$
}

\begin{abstract}
Background: Excessive consumption of energy is a decisive factor of obesity, but a simple quantitative assessment of consumption between obese and eutrophic individuals not always explains the problem, raising questions about the importance of the qualitative aspects of food. Therefore, the purpose of this study was to evaluate the differences in nutrient composition and meal patterns between eutrophic and obese schoolchildren.

Methods: The diet of 83 children (42 obese and 41 eutrophic), aged between 7 and 11 years of age, was assessed by two non-consecutive dietary recalls. After the software analysis of macro and micronutrients composition, the different types and amount of legumes, fruits and vegetables were analyzed to verify the dietary patterns.

Results: No differences were verified in energy consumption between the groups (eutrophic $=1934.2 \pm 672.7 \mathrm{kcal}$, obese $=1835.8 \pm 621.2 \mathrm{kcal}$ ). In general, children showed consumption within the recommended ranges of carbohydrates, lipids and proteins. The average consumption of fiber was higher in the eutrophic group (20.7 g) when compared to the obese group (14.8 g). The dietary fiber was strongly correlated with the number of servings of beans $(r=0.77)$, when compared to fruits $(r=0.44)$ and leafy vegetables $(r=0.13)$. It was also observed that the higher the consumption of fiber and beans, the lower the proportion of dietary fat $(r=-0.22)$ in the diet. Generally, there was a low consumption of fiber $(20.7 \mathrm{~g}=$ eutrophic group $/ 14.8 \mathrm{~g}=$ obese group), beans (1.1 portions in the eutrophic and obese groups), fruits ( 0.7 portions eutrophic group and 0.6 obese group) and vegetables (1.3 eutrophic group and 1.1 obese group).
\end{abstract}

Conclusions: It is concluded that the obesity was more related to a dietary pattern of low intake of dietary fiber than excessive energy consumption and macronutrients imbalance.

\section{Background}

Globally, children and adolescents are getting fatter and this situation seems irreversible [1-3]. A larger body size is not the main problem of obesity, but the numerous complications followed by it, such as, hypertension, dyslipidemia and type 2 diabetes [4].

Genetic, physiological and metabolic factors can influence the outcome of obesity. However, the factors that could explain the growing number of obese children appear to be more related to changes in lifestyle and eating habits $[5,6]$.

\footnotetext{
* Correspondence: mrmolive@ibb.unesp.br

† Contributed equally

${ }^{1}$ Food and Nutrition Department, School of Pharmaceutical Sciences at the São Paulo State University (UNESP), road Araraquara-Jau km1, CP 502, 14801902, Araraquara, SP - Brasil

Full list of author information is available at the end of the article
}

An increased energy intake and changes in meal patterns, such as replacement of family meals with processed foods, may be important contributors to weight gain [7-9].

In different regions of Brazil, studies are indicating a change in meal pattern. According to the Brazilian household budget survey, from $2002 / 03$ to $2008 / 09$, the consumption of beans and rice decreased in the population, while there was an increase in the consumption of soft drinks, beer and mineral water [10].

The average annual per capita purchase decreased $40.5 \%$ for milled rice (24.5 $\mathrm{kg}$ to $14,6 \mathrm{~kg}$ ) and $26.4 \%$ for beans $(12.4 \mathrm{Kg}$ to $9.1 \mathrm{~kg}$ ) in this period. Fruits and vegetables accounted for only $2.8 \%$ of the total calories in the year of 2008 [10]. A greater exposure to processed foods with high levels of energy, saturated fat and cholesterol combined with a low intake of vegetables, fruits and

\section{Biomed Central}


legumes may in part contribute to the increase of overweight and obesity in adults and children.

Thus, this study aims to evaluate the differences in nutrient composition and the meal patterns between eutrophic and obese schoolchildren.

\section{Results}

\section{Energy and macronutrients consumed by eutrophic and} obese children

Regarding the macronutrients, proteins, carbohydrates and fat were analyzed as well as the energy consumption. No differences were observed in the consumption of macronutrients and energy between eutrophic and obese children (table 1). Most students, regardless of the group, consumed the macronutrients according to the Dietary Reference Intakes (DRIs) recommendation (table 1).

\section{Dietary fiber and portions of food (beans, fruits, leafy vegetables and vegetables) consumed by eutrophic and obese children}

The consumption of dietary fiber was statistically different between the groups, being higher in the eutrophic group (table 1). The correlations between the dietary fiber and BMI, waist circumference percent body fat were weak and negative, but statistically significant (table 2). It was verified that the number of bean servings ( $\mathrm{S}$. beans) presented a strong correlation with dietary fiber $(\mathrm{g})$, whereas, the servings of fruits presented weak correlation and vegetables and leafy vegetables presented null correlation (table 3).

Overall, in the eutrophic group the correlations of fiber with fruits and beans were stronger when compared to the obese group. In the eutrophic group, the correlation between fiber and beans was strong, while in the obesity group the correlation was medium. Students in the eutrophic group consumed an average of $1.1 \mathrm{~S}$. beans, 0.7 serving of fruit and 1.3 servings of leafy vegetables and vegetables. The obese group consumed an average of 1.1 S. beans, 0.6 serving of fruit, 1.1 servings of leafy vegetables and vegetables. In the eutrophic group, the most consumed fruits were apple $(41.9 \%)$, banana $(16.0 \%)$, watermelon (15.2\%), tangerine (11.2\%) and other fruits $(15.7 \%)$ and in the obesity group, they were apple (30.3\%), banana $(26.3 \%)$, orange $(14.8 \%)$, Mango $(7.3 \%)$ and other fruits (21.3\%).

In table 4, the children were divided into tertiles according to the consumption of beans, in ascending order (from the lowest to the highest consumption of S. beans). In the total sample (obese + eutrophic children), as the intake of $\mathrm{S}$. beans increased, the amount of fiber and iron also increased while the proportion of fat decreased.
Table 1 Comparison of the adequacy of nutrient and energy consumption between the eutrophic and obese children

\begin{tabular}{|c|c|c|c|}
\hline \multirow{2}{*}{$\begin{array}{c}\text { Energy } \\
\text { and Nutrients }\end{array}$} & \multicolumn{2}{|c|}{ Children } & \\
\hline & $\begin{array}{l}\text { Eutrophic } \\
(\mathrm{n}=41)\end{array}$ & $\begin{array}{c}\text { Obese } \\
(n=42)\end{array}$ & \\
\hline & Mean \pm sd & Mean \pm sd & $p$-value* \\
\hline Energy consumption - kcal & $1934.2 \pm 672.7$ & $1835.8 \pm 621.2$ & 0.491 \\
\hline Protein- $g$ & $73.6 \pm 30.1$ & $73.1 \pm 25.2$ & 0.822 \\
\hline Carbohydrate- $g$ & $284.9 \pm 93.6$ & $270.3 \pm 95.5$ & 0.483 \\
\hline Fat $-g$ & $57.6 \pm 29.2$ & $52.6 \pm 25.3$ & 0.397 \\
\hline Dietary fiber - $g$ & $20.7 \pm 11.4$ & $14.8 \pm 9.1$ & 0.011 \\
\hline Iron-mg & $15.7 \pm 3.0$ & $14.3 \pm 2.7$ & 0.243 \\
\hline Vitamin A - mcg & $512.6 \pm 316.3$ & $917.2 \pm 534.2$ & 0.028 \\
\hline Vitamin C - mg & $63.07 \pm 56.3$ & $64.4 \pm 53.3$ & 0.986 \\
\hline Calcium -mg & $\begin{array}{c}678.6 \pm 295.9 \\
n(\%)\end{array}$ & $\begin{array}{c}613.8 \pm 295.3 \\
n(\%)\end{array}$ & 0.320 \\
\hline \multicolumn{4}{|l|}{ Protein: } \\
\hline Low intake & $5(12.2)$ & $1(2.4)$ & $\begin{array}{l}\rho=0.084 \\
\chi^{2}=3.000\end{array}$ \\
\hline Adequate intake & $36(87.8)$ & $41(97.6)$ & \\
\hline High intake & $0(0.0)$ & $0(0.0)$ & \\
\hline \multicolumn{4}{|l|}{ Carbohydrate: } \\
\hline Low intake & $1(2.4)$ & $0(0.0)$ & $\begin{array}{l}\rho=0.593 \\
\chi^{2}=1.047\end{array}$ \\
\hline Adequate intake & $33(80.5)$ & $35(83.3)$ & \\
\hline High intake & $7(17.1)$ & $7(16.7)$ & \\
\hline \multicolumn{4}{|l|}{ Fat: } \\
\hline Low intake & $19(46.3)$ & $22(52.4)$ & $\begin{array}{l}\rho=0.435 \\
\chi^{2}=0.805\end{array}$ \\
\hline Adequate intake & $19(46.3)$ & $18(42.9)$ & \\
\hline High intake & $3(7.3)$ & $2(4.8)$ & \\
\hline \multicolumn{4}{|l|}{ Dietary fiber: } \\
\hline Low recommended & $70.7(29)$ & $92.9(39)$ & $\begin{aligned} \rho & =0.019 \\
\chi^{2} & =5.447^{* *}\end{aligned}$ \\
\hline $\begin{array}{l}\text { Recommended } \\
\text { Iron: }\end{array}$ & $29.3(12)$ & $7.1(3)$ & \\
\hline Inadequate intake & $0(<1.0)$ & $0(<1.0)$ & \\
\hline Adequate intake & $41(>99.0)$ & $42(>99.0)$ & \\
\hline \multicolumn{4}{|l|}{ Vitamin A: } \\
\hline Inadequate intake & $27(66.0)$ & $7(16.0)$ & $\begin{array}{l}\rho<0.0001 \\
\chi^{2}=20.756\end{array}$ \\
\hline $\begin{array}{c}\text { Adequate intake } \\
\text { Vitamin C: }\end{array}$ & $14(34.0)$ & $35(84.0)$ & \\
\hline Inadequate intake & $11(27.0)$ & $4(9.0)$ & $\begin{array}{l}\rho=0.078 \\
\chi^{2}=3.109\end{array}$ \\
\hline Adequate intake & $30(73.0)$ & $38(91.0)$ & \\
\hline \multicolumn{4}{|l|}{ Calcium: } \\
\hline Low recommended & $38(92.7)$ & $40(95.0)$ & $P=0.625$ \\
\hline Recommended & $3(7.3)$ & $2(5.0)$ & $\chi^{2}=0.239^{* *}$ \\
\hline
\end{tabular}

*by student-t test between the eutrophic and obese children; **by Yates' chisquare test 
Table 2 Correlation between dietary fiber and anthropometric variables of the schoolchildren

\begin{tabular}{lc}
\hline Measures & $\begin{array}{c}\text { Dietary fiber consumed per gram } \\
(\mathbf{n}=\mathbf{8 3})\end{array}$ \\
\hline BMI $\left(\mathrm{kg} / \mathrm{m}^{2}\right)$ & $r(p$-value) \\
& $-0.313(0.004)$ \\
Waist Circumference $(\mathrm{cm})$. & $-0.281(0.010)$ \\
Percentage of body fat & $-0.296(0.007)$ \\
\hline
\end{tabular}

*by Pearson correlation; BMI = body mass index

Among the eutrophic children, the higher the consumption of beans, the higher the amount of dietary fiber. The obese children from the first tertile presented low amount of fiber in the diet when compared to other tertiles. In the third tertile, the eutrophic children consumed more fiber than the obese children.

In the eutrophic group, it was possible to observe that the proportion of fat in the diet was higher in the first tertile when compared to the second and third tertiles, the same was not verified in the obese group.

In general, there was a tendency of higher amount of iron as the intake of beans increased. The eutrophic children from the third tertile presented higher amount of iron in the diet when compared to children from other tertiles. The obese children from the third tertile of $\mathrm{S}$. beans had greater amount of iron in the diet when compared to children from the first tertile (table 4).

A weak and negative correlation was found between the proportion of fat and the amount of dietary fiber consumed $(\mathrm{r}=-0.36 ; p=0.001)$.

\section{Micronutrients consumed by the eutrophic and obese children}

Regarding the micronutrients, calcium, iron, vitamin C and vitamin A were analyzed. Most micronutrients were properly consumed, regardless of the group. Vitamin A was consumed in higher amount by the obese group $(917.2 \pm 534.2 \mathrm{mcg})$ when compared to the eutrophic group $(512.6 \pm 316.3 \mathrm{mcg})(\mathrm{p}=0.0278)$. As a consequence, the adequacy of vitamin $\mathrm{A}$ intake was higher in the obese
Table 4 Amount of dietary fiber, iron and proportion of fat in the diet according to the amount of servings of beans consumed by eutrophic and obese children

\begin{tabular}{|c|c|c|c|}
\hline \multirow[b]{2}{*}{ Groups } & \multicolumn{3}{|c|}{ Variables } \\
\hline & $\begin{array}{l}\text { Dietary } \\
\text { Fiber } \\
\text { (g) }\end{array}$ & $\begin{array}{l}\text { Proportion of fat in } \\
\text { diet (\%) }\end{array}$ & $\begin{array}{l}\text { Iron in } \\
\text { diet } \\
\text { (mg) }\end{array}$ \\
\hline & Mean \pm sd & Mean \pm sd & $\begin{array}{c}\text { Mean } \pm \\
\text { sd }\end{array}$ \\
\hline \multicolumn{4}{|l|}{$\begin{array}{l}\text { Eutrophic children } \\
\text { (41) }\end{array}$} \\
\hline $\begin{array}{l}\text { First tertile S. } \\
\text { Beans }\end{array}$ & $9.9 \pm 4.8^{\mathrm{ad}}$ & $28.8 \pm 6.7 a$ & $\begin{array}{l}12.5 \pm \\
4.2 \mathrm{ac}\end{array}$ \\
\hline $\begin{array}{l}\text { Second tertile } \mathrm{S} \text {. } \\
\text { Beans }\end{array}$ & $20.3 \pm 5.7^{b}$ & $24.9 \pm 4.3^{b}$ & $\begin{array}{l}13.4 \pm \\
3.3^{\mathrm{a}}\end{array}$ \\
\hline $\begin{array}{l}\text { Third tertile S. } \\
\text { Beans }\end{array}$ & $31.3 \pm 6.3^{c}$ & $22.0 \pm 5.3^{b}$ & $\begin{array}{c}20.2 \pm \\
5.9^{b}\end{array}$ \\
\hline \multicolumn{4}{|l|}{ Obese children (42) } \\
\hline $\begin{array}{l}\text { First tertile } \mathrm{S} . \\
\text { Beans }\end{array}$ & $8.4 \pm 3.0^{a}$ & $26.4 \pm 6.3^{a b}$ & $\begin{array}{c}11.6 \pm \\
4.4^{a}\end{array}$ \\
\hline $\begin{array}{l}\text { Second tertile S. } \\
\text { Beans }\end{array}$ & $15.7 \pm 7.5^{\mathrm{bd}}$ & $26.1 \pm 5.0^{\mathrm{ab}}$ & $\begin{array}{l}14.1 \pm \\
4.5^{\mathrm{ca}}\end{array}$ \\
\hline $\begin{array}{l}\text { Third tertile S. } \\
\text { Beans }\end{array}$ & $17.9 \pm 6.6^{b}$ & $23.2 \pm 5.9^{b}$ & $\begin{array}{l}17.0 \pm \\
5.0^{\mathrm{bc}}\end{array}$ \\
\hline$P$ - Value* & $p<0.00001$ & 0.030 & $\begin{array}{c}p< \\
0.00001\end{array}$ \\
\hline \multicolumn{4}{|l|}{ Total sample (83) } \\
\hline $\begin{array}{l}\text { First tertile } \mathrm{S} . \\
\text { Beans }\end{array}$ & $9.3 \pm 4.1^{e}$ & $27.6 \pm 6.6^{e}$ & $4.2^{e^{ \pm}}$ \\
\hline $\begin{array}{l}\text { Second tertile S. } \\
\text { Beans }\end{array}$ & $16.9 \pm 6.9^{f}$ & $25.5 \pm 4.5^{e}$ & $\begin{array}{c}13.9 \pm \\
4.8^{\mathrm{e}}\end{array}$ \\
\hline $\begin{array}{l}\text { Third tertile } \mathrm{S} \text {. } \\
\text { Beans }\end{array}$ & $24.4 \pm 8.9^{9}$ & $22.6 \pm 5.7^{f}$ & $\begin{array}{l}18.4 \pm \\
5.2^{f}\end{array}$ \\
\hline$P$ - Value ${ }^{*}$ & $p<0.00001$ & 0.010 & $\begin{array}{c}p< \\
0.00001\end{array}$ \\
\hline
\end{tabular}

* = by ANOVA between the eutrophic and obese children, same letters in the same column accompanying the values indicate that the values do not differ according to the Tukey test, after ANOVA $(p<0.05)$;

group (84\%) when compared to the eutrophic group (34\%). Calcium consumption, regardless of the group, was below the recommended value of adequate intake (AI), $($ eutrophic group $=92.7 \%$; obese group $=95 \%)($ Table 1$)$.

Table 3 Correlations between dietary fiber and consumed portions of beans, fruits and vegetables, according the children groups

\begin{tabular}{|c|c|c|c|c|c|c|}
\hline \multirow{3}{*}{ Servings } & \multicolumn{6}{|c|}{ Dietary fiber (g) } \\
\hline & \multicolumn{2}{|c|}{$\begin{array}{c}\text { Total } \\
\text { Sample } \\
(n=83)\end{array}$} & \multicolumn{2}{|c|}{$\begin{array}{c}\text { Eutrophic } \\
\text { Children } \\
(\mathrm{n}=41)\end{array}$} & \multicolumn{2}{|c|}{$\begin{array}{l}\text { Obese } \\
\text { Children } \\
(n=42)\end{array}$} \\
\hline & $r^{*}$ & $p$-Value & $r^{*}$ & $p$-Value & $r^{*}$ & $p$-Value \\
\hline Beans & 0.769 & $p<0.0001$ & 0.898 & $p<0.0001$ & 0.672 & $p<0.0001$ \\
\hline Fruits & 0.418 & $p<0.0001$ & 0.484 & 0.001 & 0.299 & 0.054 \\
\hline Vegetable & 0.059 & 0.596 & 0.233 & 0.142 & -0.185 & 0.240 \\
\hline Leafy vegetable & 0.126 & 0.255 & 0.19 & 0.246 & 0.02 & 0.924 \\
\hline
\end{tabular}

*by Pearson correlation 


\section{Discussion}

The study compared and established differences between nutrient composition and the meal patterns of obese and eutrophic students. Between the groups, there were no differences in total energy and the amount of macronutrients consumed, except for the intake of dietary fiber, which was higher in the eutrophic group, indicating differences in dietary pattern.

Although the benefits of fiber are already a consensus, the role of fiber in the regulation of body weight is not highly valued, focusing more on the effects of energy and fat content in a diet. According to Slavin et al (2005) [11], this situation occurs because when the diet is low in fiber, it is usually high in calories and fat, therefore the effects of fiber can be masked. Despite the fact the amount of calories have become the focus of attention, some studies have found that nutritional balance is the predominant factor for obesity prevention [11-13].

Several studies have found associations between dietary fiber and anthropometric measures [14-20]. There are several mechanisms by which dietary fiber may regulate body weight, such as intrinsic effects (chewing and palatability), effects of the colon (production of short chain fatty acids) and hormonal effects (decreased insulin and increased Cholecystokinin) [20,21].

Among these mechanisms, the increase in the intestinal transit was what could have mostly contributed to the regulation of body weight in this present study, considering that high intakes of dietary fiber are associated with increased fecal loss of energy, fat and nitrogen [22]. Also, there were no differences in energy intake between the groups, showing that the fiber did not have any influence in satiety.

Beans were the main food that influenced the amount of dietary fiber. It is believed that dried beans were more consumed because they last longer after the purchase. Besides, they have a historical importance in the Brazilian nutrition, being responsible for nutritional survival of most Brazilians [23].

In addition to the high protein content, beans have high amounts of soluble fiber, soluble vitamins and minerals. Considering these qualities, some countries are specifying the amount of daily servings of dried beans to be consumed by the population $[24,25]$ and studies have confirmed that the intake of beans increases the quality of the diet, $[17,26]$ while decreasing the amount of saturated fat and total fat [26].

In this study, it was determined that the higher the intake of beans, the higher the amount of fiber and iron and the lower the proportion of fat in the diet. This lower proportion of fat was evident in the eutrophic group. In this group, the higher intake of beans may have contributed to the lower intake of other energy-dense food, high in fat.

In the eutrophic group, a better correlation was verified between beans and fiber was verified when compared to the obese group, perhaps because in the third tertile of S. beans the eutrophic group had a higher intake of fiber. In some studies, the consumption of beans has influenced the weight loss of individuals [18,27-29].

It is presumed that the children who did not consume beans replaced a family meal with food that presented low fiber content but similar energy density. Foods that have the same amount of total energy but different amounts of fiber can exert distinct effects on body weight regulation [30].

This substitution can be confirmed by a higher adequacy in the consumption of vitamin A among obese children. It is assumed that this greater amount is related to increased intake of processed foods (e.g., cookies, chocolate powder) whose target are children. They are often enriched with vitamins and minerals, but hide high contents of fat, sugar and sodium.

Regarding the fruits, worrying results were found due to the low consumption. Most students did not consume fruits. The children in this study come from low income families and usually, in this situation, fruits are bought only once a month. The eutrophic group showed stronger correlation between the consumption of fruits and fiber compared to the obese group. This difference may be due to the different types of fruits consumed. In the eutrophic group, apples were more consumed than in the obese group. The pectin, which is the main fiber of this fruit, seems to benefit the weight loss [15].

Also in the eutrophic group, the tangerine was the favorite citrus fruit and according to the Brazilian nutritional database, it has a better source of fiber when compared to orange [31]. In general, calcium intake was below the recommended AI, being this is a reflection of low milk consumption, which has been reported in some studies [9,32].

During the family meal, the intake of rice with beans is traditional, but this dietary pattern is changing. The consumption of beans is decreasing, especially among young people [33]. In this present study, the low consumption of this legume and other vegetables influenced the large inadequacy of fiber intake in the groups. The urbanization favors this decline, once it contributes to the short time to prepare a homemade meal and moreover, the fast foods have more appeal due to the better palatability found in fat and sugar $[34,35]$. This preference for sweets and fat -energy dense foods over grains, legumes and vegetables is not restricted to Brazilian children; other countries are experiencing the same situation [36,37]. 
Recent reviews have shown association between skipping meals and an increased overweight and obesity risk in children [38,39], with an emphasis on low consumption of breakfast [39]. Increased meal frequency not only avoids high-fat, energy-dense foods and soft drinks consumption but also reduces postprandial metabolic and endocrine responses due to nutrient consumption, with lower insulin secretion [38,39].

Finally, although the influence of energy intake in weight gain was not verified, underreport and forgetfulness cannot be ignored. Children, especially obese, may be embarrassed to report the "unhealthy" food and children who replace meals with many snacks during the day may not be aware of all the food that is being consumed, underestimating the total energy of the diet. Considering the short time parents had to take part in this study, we had some limitations with the small sample size. However, we believe that this study showed some interesting results that should be investigated with a bigger sample size.

\section{Conclusions}

The results indicate that low intake of dietary fiber is associated with risk for obesity; this consumption was strongly linked to the consumption of servings of beans. This reinforces the importance of traditional family meals, which are being daily replaced with snacks and processed foods. The child's nutrition is an important factor in health, considering that the eating habit formed in childhood can persist throughout the adulthood, influencing the quality of life of the individuals.

\section{Methods}

\section{Recruitment}

This study, derived from a main project titled: "Risk factors for chronic diseases in obese schoolchildren", was developed in a São Paulo inner city with 7 to 11 yearold children enrolled in six elementary public schools. The total sample was 83 children, being 42 obese and 41 eutrophic. The study was submitted to the research ethics committee for approval at Unesp - Araraquara (Protocol Number. 31/2005). Only children whose guardians agreed to and signed a consent form took part in this study.

Children with obesity ( $\geq 95$ th percentile for the ageand sex-specific BMI values according to the U.S. Growth Chart 2000) and with eutrophy (percentile for the age - and sex-specific BMI values between 5 and 85) [40] were recruited. In table 5, the anthropometric characteristics of children who participated in the study are described, confirming high values of BMI, waist circumference and body fat percentage in the obese group when compared to the eutrophic group.
Table 5 Anthropometric variables and age of the obesity and eutrophic group

\begin{tabular}{cccc}
\hline Measures & $\begin{array}{c}\text { Groups } \\
\text { Eutrophic } \\
(\mathbf{n}=\mathbf{4 1})\end{array}$ & $\begin{array}{c}\text { Obesity } \\
\mathbf{( n = 4 2 )}\end{array}$ & p-value* \\
\hline Age $($ Year $)$ & $8.9 \pm 1.0$ & $8.9 \pm 1.0$ & 0.9209 \\
BMl $\left(\mathrm{kg} / \mathrm{m}^{2}\right)$ & 18.6 & 29.4 & \\
$90^{\text {th }}$ & $16.4 \pm 1.5$ & $25.1 \pm 4.0$ & $\mathrm{p}<0.00001$ \\
Mean $\pm \mathrm{sd}$ & 14.8 & 21.1 & \\
$10^{\text {th }}$ & & & \\
Waist circumference $(\mathrm{cm})$ & 63.0 & 89.3 & $\mathrm{p}<0.00001$ \\
$90^{\text {th }}$ & $57.2 \pm 5.0$ & $78.1 \pm 8.8$ & \\
Mean \pm sd & 51.1 & 66.1 & \\
$10^{\text {th }}$ & & & \\
Body fat percentage $(\%)$ & 29.0 & 54.3 & \\
$90^{\text {th }}$ & $20.4 \pm 6.7$ & $39.9 \pm 9.6$ & $\mathrm{p}<0.00001$ \\
Mean \pm sd & 12.0 & 31.0 & \\
$10^{\text {th }}$ & & & \\
\hline
\end{tabular}

* by student-t test; $\mathrm{BMI}=$ body mass index

\section{Anthropometry}

For the anthropometric measures, the schoolchildren were barefoot with minimum clothes. A properly calibrated digital scale, Plenna ${ }^{\circledR}$ brand with a $150 \mathrm{~kg}$ capacity was used for weighing. The height was measured with a TBW ${ }^{\circledR}$ stadiometer. Circumference of waist was measured following the protocol of Callaway et al (1988) [41]. The percentage of body fat was measured by impedance with a portable foot to foot scale Tanita ${ }^{\circledR}$ TBF 310, this model has been validated to be used in children [42] and in groups of obese children [43].

\section{Food Intake assessment}

Food intake was evaluated through two non-consecutive $24 \mathrm{~h}$ food recalls. This method is considered a standard reference and has already been validated in previous studies $[44,45]$. With the help of an album of photographs and kitchen utensils, the students were asked to report everything that was consumed during the previous 24 hours. The amount of food consumed was recorded in household measures, transformed into grams and then converted into numbers of food servings, according to the energetic equivalence of each food group pyramid.

To estimate the intake of energy and nutrients, foods (in grams) were reported and analyzed by a program of Nutrition (NutiWin ${ }^{\circledR}$ ) [46].

The percentage distribution of energy among the macronutrients was analyzed according to the cutoff points of the Acceptable Macronutrients Distribution Range - DRIs. When the proportion of energy from protein was lower than $10 \%$, it was considered low intake and above $30 \%$, it was considered as high. When the intake of Carbohydrate was below $45 \%$, it was considered low, when it was above $65 \%$, the consumption was 
considered high. A high intake of fat was considered above $35 \%$, a low intake was considered below $25 \%$ [47].

To assess the adequacy of iron, vitamin $\mathrm{C}$ and vitamin A intakes, we used the EAR's (Estimated Average Requirement), from DRI's. The EARs can be defined as the average nutrient amount for a given stage of life and gender and it is a value of reference that was used to be compared to the average amount of micronutrients consumed by the groups of children $[48,49]$. The micronutrient that did not present the EAR value (calcium and fiber) was evaluated by the AI from DRI's. This value does not determine the inadequate intake, but just the recommended intake for healthy people [50]. Then, to estimate the proportion of individuals consuming above or below the EAR, considering the variation of inter-and intra-personal consumption, we applied a statistical method to remove day-to-day variability, reflecting only the change in consumption between individuals from the group [51].

\section{Statistical Analysis}

For statistics, we used Microsoft Excel (2003) and Bioestat 5 programs. Differences in group averages were analyzed by student-t test. Anova one criterion was used to test differences in tertile averages. The relation between data was tested by Pearson correlation. The correlation coefficients were classified as perfect $(=1.00)$, strong $(>0.75)$, medium $(>0.5)$, weak $(<0.5)$, and null $(=0.00)$. Differences among proportions of nominal data were tested by chi-square $\left(\chi^{2}\right)$ and by Yates' chi-square test when necessary. The level of significance was $5 \%$ in all comparisons. The normality of the data was analyzed with Lilliefors test.

\section{Acknowledgements and funding}

The first author received a master scholarship from CNPq

\section{Author details}

${ }^{1}$ Food and Nutrition Department, School of Pharmaceutical Sciences at the São Paulo State University (UNESP), road Araraquara-Jau km1, CP 502, 14801 902, Araraquara, SP - Brasil. ²Education department, Biosciences Institute, São Paulo State University (UNESP), District Rubião junior, CP 510, 18618-000, Botucatu, SP - Brasil.

\section{Authors' contributions}

$E A B$ and MRMO designed and initiated the study. EAB performed the statistical analyses. All authors helped gather and interpret data and write the article. All authors approved the final version of the article. The study was submitted for approval by the ethics committee research form the faculty of Pharmaceutical Sciences of Unesp - Araraquara (protocol No. 31/ 2005). There are no conflicting interests regarding the funding of the study

\section{Competing interests}

The authors declare that they have no competing interests.

Received: 13 May 2011 Accepted: 29 December 2011

Published: 29 December 2011

\section{References}

1. Wang Y, Monteiro C, Popkin BM: Trends of Obesity and Underweight in older children and adolescents in the United States, Brazil, China, and Russia. Am J Clin Nutr 2002, 75:971-977.
2. Instituto Brasileiro de Geografia e Estatística: Pesquisas de Orçamentos familiares 2008-2009: Antropometria e estado nutricional de crianças e adolescentes e adultos no Brasil. Rio de Janeiro: Instituto Brasileiro de Geografia e Estatística; 2010.

3. Centers for Diseases Control and Prevention: Data and statistics: Obesity rates among all children in the United States. [Acess 13 may 2011]. Atlanta 2011, Available from: http://www.cdc.gov/obesity/childhood/data.html.

4. Dietz WH: Health consequences of obesity in youth: Childhood predictors of adult. Pediatrics 1998, 101:518-24.

5. Hopin AG: Assessment and management of childhood and adolescent obesity. Medscape 2005, 1-29.

6. Popkin BM: Global nutrition dynamics: the world is shifiting rapidly toward a diet linked with noncommunicable diseases. Am J Clin Nutr 2006, 84:289-98.

7. Mendez MA, Popkin BM: Globalization, Urbanization and Nutritional Change in the Developing World. eJADE 2006, 1:220-241.

8. Young LR, Nestle M: The contribution of expanding portion sizes to the US obesity epidemic. Am J Pub Health 2002, 92:246-249.

9. Nielsen SJ, Popkin BM: Changes in Beverage Intake between 1977-2001. Am J Prev Med 2004, 27:205-210.

10. Instituto Brasileiro de Geografia e Estatística: Pesquisas de Orçamentos familiares: Aquisição alimentar domiciliar per capita: Brasil e Grandes Regiões. Rio de Janeiro: Instituto Brasileiro de Geografia e Estatística; 2010

11. Slavin JL: Dietary fiber and body weight. Nutrition 2005, 21:411-418.

12. Bolton RP, Heaton KW, Burroughs LF: The role of dietary fiber in satiety, glucose, and insulin: studies with fruit and fruit juice. Am J Clin Nutr 1981, 34:211-217.

13. Harber GB, Heaton KW, Murphy D, Burroughs LF: Depletion and disruption of dietary fibre. Effects on satiety, plasma-glucose, and serum insulin. Lancet 1977, 2:679-682.

14. de Carvalho EB, Vítolo MR, Gama CM, Lopez FA, Taddei JA, de Morais MB: Fiber intake, constipation, and overweight among adolescents living in Sao Paulo City. Nutrition 2006, 22:744-749.

15. Oliveira CM, Sichiere R, Moura AS: Weight loss associated with a daily intake of three apples or three pears among overweight women. Nutrition 2003, 19:253-256.

16. Howarth NC, Huang TT, Roberts SB, McCrory MA: Dietary fiber and fat are associated with excess weight in young and middle-aged US adults. J Am Diet Assoc 2005, 105:1365-1372.

17. Davis JN, Hodges VA, Gillham MB: Normal Weight Adults Consume More Fiber and Fruit than their Age- and Height-Matched Overweight/Obese counterparts. J Am Diet Assoc 2006, 106:833-840.

18. Papanikolaou Y, Fulgoni VL: Bean consumption is associated with greater nutrient intake, reduced systolic blood pressure, lower body weight, and a smaller waist circumference in adults: results from the National Health and Nutrition Examination Survey 1999-2002. J Am Coll Nutr 2008, 27:569-576.

19. Maki KC, Beiseigel JM, Jonnalagadda SS, Gugger CK, Reeves MS, Farmer MV, Kaden VN, Rains TM: Whole-Grain Ready-to-Eat Oat Cereal, as Part of a Dietary Program for Weight Loss, Reduces Low-Density Lipoprotein Cholesterol in Adults with Overweight and Obesity More than a Dietary Program Including Low-Fiber Control Foods. J Am Diet Assoc 2010, 110:205-214.

20. Pereira MA, Ludwig DS: Dietary fiber and body-weight regulation. Observations and mechanisms. Pediatr Clin North Am 2001, 48:969-980.

21. Kendall CW, Esfahani A, Jenkins DJA: The link between dietary fibre and human health. Food Hydrocol 2009, 24:42-48.

22. Southgate DAT, Durnin JVGA: Calorie conversion factors-an experimental reassessment of factors used in calculation of energy value of human diets. Br J Nutr 1970, 24:517-35.

23. Ministério da Agricultura, Pecuária e Abastecimento: Empresa Brasileira de Pesquisa Agropecuária (EMBRAPA). Feijão na economia nacional. Santo António Goiás: Embrapa Arroz e Feijão; 2002.

24. Britten P, Marcoe K, Yamini S, Davis C: Development of food intake patterns for the My Pyramid Food Guidance System. J Nutr Educ Behav 2006, 38:78-92

25. Ministério da Saúde, Secretaria de Atenção à Saúde. Guia alimentar para a população brasileira: promovendo a alimentação saudável. Brasília: Ministério da saúde; 2008.

26. Mitchell DC, Lawrence FR, Hartman TJ, Curran JM: Consumption of dry beans, peas, and lentils could improve diet quality in the US population. J Am Diet Assoc 2009, 109:909-913. 
27. Hermsdorff HH, Zulet MA, Abete I, Martinez JA: A legume-based hypocaloric diet reduces pro inflammatory status and improves metabolic features in overweight/obese subjects. Eur J Nutr .

28. Sichieri R: Dietary patterns and their associations with obesity in the Brazilian city of Rio de Janeiro. Obes Res 2002, 10:42-48.

29. Cunha DB, de Almeida RM, Sichieri R, Pereira RA: Association of dietary patterns with $\mathrm{BMI}$ and waist circumference in a low-income neighborhood in Brazil. Br J Nutr 2010, 104:908-913.

30. Duarte HS, Monteiro JBR, Costa NMB: Efeito de uma sopa rica em fibra sobre a ingestão alimentar, peso e composição corporal. Re Bras Nutr Clin 1999, 14:228-238.

31. Brasil. Tabela Brasileira de Composição de alimentos/NEPA - UNICAMP. Campinas: Nepa-Unicamp; 2006.

32. O'Connor TM, Yang SJ, Nicklas TA: Beverage intake among preschool children and its effect on weight status. Pediatrics 2006, 118(4):1010-1018.

33. Leterme $P$, Munoz LC: Factors influencing pulse consumption Latin America. Br J Nutr 2002, 88:251-254.

34. Uauy $\mathrm{R}$, Monteiro CA: The challenge of improving food and nutrition in Latin America. Food Nutr Bull 2004, 25:175-182.

35. Tardido $A P$, Falcão MC: $O$ impacto da modernização na transição nutricional e obesidade. Rev Bras Nutr Clin 2006, 21:117-124.

36. Gharib N, Rasheed P: Energy and macronutrient intake and dietary pattern among school children in Bahrain: a cross-sectional study. Nutr J 2011, 10(62):1-12.

37. Aounallah-Skhiri $H$, Traissac $P$, Ati JE, Eymard-Duvernay $S$, Landais $E$, Achour N, Delpeuch F, Romdhane HB, Maire B: Nutrition transition among adolescents of a south-Mediterranean country: dietary patterns, association with socio-economic factors, overweight and blood pressure. A cross-sectional study in Tunisia. Nutr J 2011, 10(38):1-17.

38. Koletzko B, Toschke AM: Meal patterns and frequencies: do they affect body weight in children and adolescents? Crit Rev Food Sci Nutr 2010, 50(2):100-105.

39. Patro B, Szajewska H: Meal patterns and childhood obesity. Curr Opin Clin Nutr Metab Care 2010, 13:300-304.

40. Kuczmarski RJ, Ogden CL, Guo SS, Grummer-Strawn LM, Flegal KM, Mei Z, et al: 2000 CDC Growth Charts for the United States: methods and development. Vital Health Stat 2002, 246:1-190.

41. Callaway CW, Chumlea WC, Bouchard C, Hilmes JH, Lohman TG, Martin AD: Circumferences. Anthropometric standardization reference manual Champaign, I.L.: Human Kinetics Edition; 1988.

42. Kettaneh A, Heude B, Lommez A, Borys JM, Ducimetière P, Charles MA: Reliability of bioimpedance analysis compared with other adiposity measurements in children: The FLVS II Study. Diabetes Metab 2005, 31:534-541.

43. Radley D, Cooke CB, Fuller NJ, Oldroyd B, Truscott JG, Coward WA, Wright A, Gately PJ: Validity of foot-to-foot bio-electrical impedance analysis body composition estimates in overweight and obese children. Int J Body Compos Res 2009, 7:15-20.

44. Willet W: Nutritional Epidemiology. New York, N.Y.: Oxford University Press; 1998.

45. Reniscow K, Odom E, Wang T, Dudley WN: Validation of Three Food Frequency Questionnaires and 24-Hour Recalls with serum Carotenoid Levels in a Sample of African-American Adults. Am J Epidemiol 2000, 152:1072-1079.

46. Programa de Apoio à Nutrição - Nutwin. Versão 1.5. Centro de Informática em Saúde da Escola Paulista de Medicina [software]. São Paulo: UNIFESP; 2002.

47. Institute of Medicine: Dietary Reference Intakes for energy, carbohydrate, fiber, fat, fatty acids, cholesterol, protein, and amino acids (Macronutrients). Washington, D.C: National Academy Press; 2002.

48. Institute of Medicine: Dietary Reference Intakes for vitamin A, vitamin K, arsenic, boron, chromium, copper, iodine, iron, manganese, molybdenum, nickel, silicon, vanadium, and zinc. Washington, D.C. National Academy Press; 2001.

49. Institute of Medicine: Dietary Reference Intakes for vitamin C, vitamin E, selenium, and carotenoids. Washington, D.C.: National Academy Press; 2000.

50. Institute of Medicine: Dietary Reference Intakes for calcium, phosphorus, magnesium, vitamin D, and fluoride. Washington, D.C.: National Academy Press; 1997.
51. Slater B, Marchioni DL, Fisberg RM: Estimando a prevalência da ingestão inadequada de nutrientes. Rev Sau Pub 2004, 38:599-605.

doi:10.1186/1756-0500-4-567

Cite this article as: Balthazar and de Oliveira: Differences in dietary pattern between obese and eutrophic children. BMC Research Notes 2011 4:567.

\section{Submit your next manuscript to BioMed Central and take full advantage of:}

- Convenient online submission

- Thorough peer review

- No space constraints or color figure charges

- Immediate publication on acceptance

- Inclusion in PubMed, CAS, Scopus and Google Scholar

- Research which is freely available for redistribution

Submit your manuscript at www.biomedcentral.com/submit
Biomed Central 